tion, and the esteem in which it is held abroad, as manifested by the spontaneous tributes received from all over the world. $\mathrm{He}$ directed attention to the traditional connexion of the ruling princes of India with the Society, and hoped that this tradition might be widened, to the benefit of scholarship, by the inclusion in the Society's list of members of the name of every substantial ruler in the country.

His Excellency paid special tribute to three members of the Society, Sir Rajendranath Mookerjee, Mr. John Van Manen (general secretary) and Dr. S. L. Hora (honorary secretary of the Celebration Committee).

\section{Research in the British Post Office}

W HEN the State purchased the telegraphs in Great Britain in 1869, the number of electrical workers in the whole country could almost be counted on the fingers. To-day the engineer-in-chief of the Post Office controls a staff of about 30,000 and maintains plant of a value of 130 million pounds. Starting from the needle instruments, skilled Post Office experimentalists developed the Wheatstone transmitter and receiver ; instruments capable of operating up to 300 words per minute.

Capt. B. S. Cohen, the engineer of the Post Office Research Station at Dollis Hill, in a paper read to the Institution of Electrical Engineers on February 1, said that these instruments still stand unsurpassed to-day in their design, workmanship and performance. It was not until 1912 that a research section was established. During the War period, the thermionic valve was perfected and at one stroke opened a boundless vista of possibilities in the way of universal telephone communication. The paramount necessity was to obtain the closest co-ordination between the research and the operating organisations. Without full access for research purposes to the working telegraph and telephone plant, the work of the research engineers would have been immensely increased. The Research Station at Dollis Hill was started in 1921 by using ex-army huts, and the permanent buildings were completed last year. Much excellent work has been done at this station which could not have been done elsewhere.

To the research workers at Dollis Hill the increase in the volume and weight of road traffic brought with it a new problem. There are apparently under the streets an ever-increasing number of cracked gas mains. Modern road surfaces make it difficult for this gas to escape into the open and so it sometimes accumulates in Post Office cable ducts and manholes, involving a serious hazard. The research engineers have developed a simple form of gas detector for general issue to Post Office workmen. The detector operates in a way somewhat similar to a photographic exposure meter. It utilises a filter paper moistened with a few drops of palladium chloride solution and will indicate the presence of 0.05 per cent of carbon monoxide, the dangerous constituent of coal gas.

The capital value of automatic switching apparatus installed in exchanges is now very large, and great precautions against corrosion have to be taken. Sir Robert Hadfield has said that the corrosion of iron and steel alone costs the world 700 million pounds per annum. Experiment shows that the life of galvanised iron stay wire is proportional to the thickness of the galvanising. In some parts of south
Lancashire, the normal life of a stay wire is little more than two years. It is now possible to estimate the life of any particular grade of wire in a given area.

In long telephone lines the 'echo' used to be very troublesome but the engineers have invented, using valves only, a very efficient echo-suppressor. A nonreflecting room at the Station has linings of cottonwool one foot thick. This room has a totally silent background of noise. It is especially useful for listening tests where the threshold of hearing has to be found.

\section{University and Educational Intelligence}

Cambridge.-At St. John's College, one Strathcona research studentship of the annual value of $£ 150$ and two Strathcona exhibitions of the annual value of $£ 40$ are offered for competition amongst research students who are graduates of any university other than Cambridge. The election of a candidate not yet a member of the College is subject to his being accepted by the University as a research student proceeding to the $\mathrm{Ph} . \mathrm{D}$. degree and to his commencing residence in October 1934. Candidates must make application to the Senior Tutor, St. John's College, not later than July 1.

London.--Dr. G. P. Wright has been appointed as from March I Sir William Dunn professor of pathology tenable at Guy's Hospital Medical School. Since 1931, Dr. Wright has been assistant lecturer in morbid anatomy and curator of the Museum at University College Hospital Medical School and also pathologist to the Hospital.

It is expected that the new British Postgraduate Medical School at Hammersmith will be opened to students in October next. It has been given recognition as a School of the University for a period of two years, as a temporary measure.

OXFord.-In presenting Miss Ethel Bellamy for the honorary degree of M.A. on January 30, the Public Orator, Mr. C. Bailey, took occasion to remind Convocation of the distinguished services rendered by that lady and other members of her family in the cause of astronomy, and particularly in the important part taken by the Oxford Observatory in the photographic survey of the heavens. In consideration of the recent help accorded to the Vatican Observatory towards the completion of that work, the Pope has bestowed on Miss Bellamy a decoration of silver.

St. Andrews.-The Court has agreed to institute a lectureship in bacteriology in the University and has appointed Mr. James F. Murray, who has hitherto been assistant to the professor of bacteriology, to the lectureship as from February 1; Mr. A. B. Stewart has been appointed to succeed Mr. Murray as assistant in the Department.

THE booklet on the new buildings of the University of London, edited by T. L1. Humberstone and published by the Dryden Press (see Nature, June 24,1933 , p. 903 ) has been withdrawn from publication and replaced by a similar book containing also a report of the stone-laying ceremony by the King on June 26. This is published by Mr. William Rice, 3 Ludgate Broadway, E.C.4, at $2 s .6 d$. 